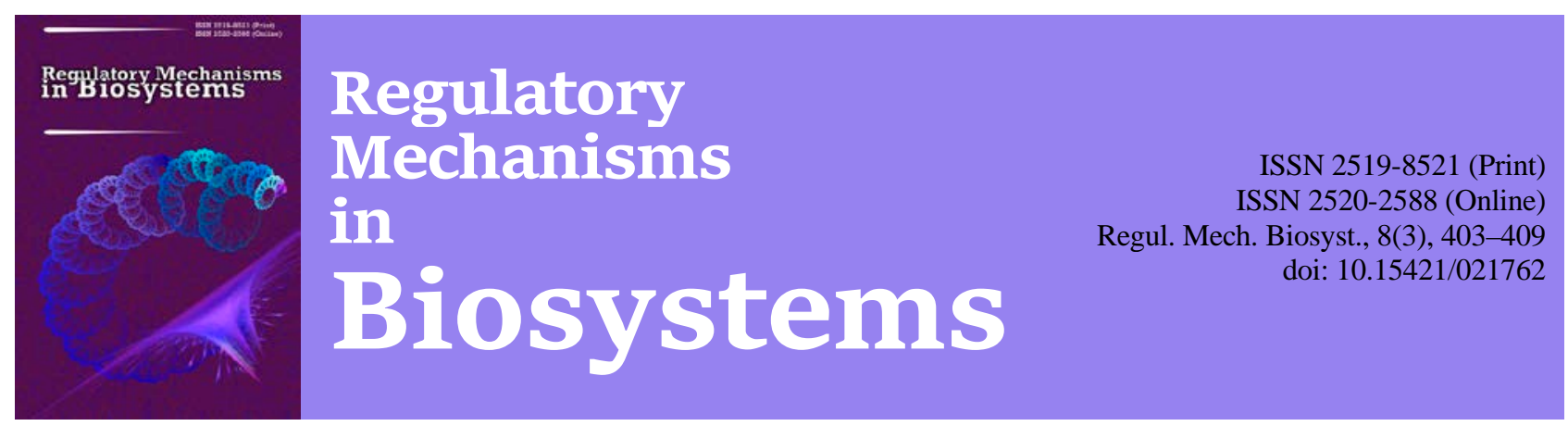

\title{
Changes in the elemental composition of winter wheat plants caused by the action of Megafol and retardants
}

\author{
I. M. Miroshnichenko, T. I. Makoveychuk, L. M. Mykhalska, V. V. Schwartau \\ Institute of Plant Physiology and Genetics of the National Academy of Sciences of Ukraine, Kyiv, Ukraine
}

Article info

Received 24.06.2017

Received in revised form 12.08.2017

Accepted 17.08.2017

Institute of Plant Physiology and Genetics of the National Academy of Sciences of Ukraine, Vasylkivska Str., 31/17, Kyiv, 03022, Ukraine

\begin{abstract}
Miroshnichenko, I. M., Makoveychuk, T. I., Mykhalska, L. M., \& Schwartau, V. V. (2017). Changes in the elemental composition of winter wheat plants caused by the action of Megafol and retardants. Regulatory Mechanisms in Biosystems, 8(3), 403-409. doi: 10.15421/021762
\end{abstract}

In the course of field experiments conducted during the 2015-2016 vegetation seasons, retardants Medax Top, 1.0 l/ha (prohexadione-Ca and mepiquat-chloride), appeared more effective than Terpal, 1.5 l/ha (mepiquat-chloride and ethephon), on field plots with high-yield varieties. Foliar application of Megafol promoted the productivity of winter wheat varieties Smuglyanka and Podolyanka and reduced the negative influence of retardants on the wheat plants in the vegetation seasons which were characterized by moisture deficit. The influence of modern retardants - prohexadione-Ca + mepiquat-chloride (Medax Top) and mepiquat-chloride + etefone (Terpal, both BASF, Germany) on the accumulation of some macro- and micronutrients in winter wheat plants was determined. The assays were performed on an ICP-MS Agilent 7700x mass spectrometer (Agilent Technologies, USA) with ICP-MS Mass Hunter WorkStation. Samples of winter wheat plants were taken in the phase of flowering and grain ripening. The samples were dried, homogenized, $0.400 \mathrm{~g}$ of weight was dissolved in ICP-grade nitric acid in the Milestone Start D (Milestone Inc., USA). All solutions were prepared on 1st class water (18 $\mathrm{M} \Omega \mathrm{cm}^{-1}$ ) obtained on the Scholar-UV Nex Up 1000 (Human Corporation, Korea) water purification system. The ICP-MS Complete Standard IV-ICPMS-71A was used as the external standard, and the internal standard was Sc, both of Inorganic Ventures, USA. According to the ICP-MS results of plant samples of winter wheat of Smuglylanka and Podolanka, it has been shown that, in conditions of wheat growing on light soils of Polissya, modern compositional retardants affect the ionome of plants during the vegetation season, as well as change the content of inorganic elements in the grain. It was found that winter wheat of the middle-stem intensive Podolyanka type reacted more responsively to retardant treatment than the short-stem highly intensive Smuglyanka type. At the same time, there was an increase in the content of nutrients in winter wheat of the Podolyanka variety. It should be noted that wheat grain of the Smuglyanka variety contained a significantly higher pool of macro- and trace elements than the Podolyanka variety. It was established that the treatment of Podolyanka winter wheat varieties by mepiquat-chloride and ethephon (Terpal, $1.5 \mathrm{l} / \mathrm{ha}$ ) positively influenced the accumulation of potassium, magnesium and calcium and manganese, copper and zinc in the grain. We found that foliar application of compositions of amino acids simultaneously with retardants can reduce the negative action of PGRs on formation of the harvest in conditions of drought and influence the maintenance of composition of inorganic elements in the plants and in the grain. The composition of retardants with the content of cyclohexadione derivative (Medax Top) also significantly influenced the changes in the content of inorganic elements in plants and grains. We note the significant increase in the content of magnesium in the leaves and in grain due to the action of Medax Top. These differences in reaction of winter wheat varieties to the action of retardants of the class of cyclohexadione are important for clarifying the systems of nutrition of crops in intensive growing technologies, especially in the conditions of drought and high temperatures. Reduction in the pools of a number of inorganic elements in plants, for example iron, by the action of retardants may be due to the constraints on the entry of these elements from the poor soils of the Polissya zone and should be compensated via foliar nutrition. Also, the peculiarities of the activity of plant growth regulators have been shown to indicate a close relationship between signal systems of plants and changes in ionome.

\section{Зміни елементного складу рослин пшениці озимої за дії Мегафолу та ретардантів}

\author{
I. М. Мірошниченко, Т. І. Маковейчук, Л. М. Михальська, В. В. Швартау
}

Інститут фізіології рослин і генетики Національної академії наук Украӥни, Київ, Україна

У польових та виробничих дослідах вегетаційних сезонів 2015-2016 рр. на посівах високопродуктивних сортів пшениці озимої ретардант Медакс Топ, 1,0 л/га (прогексадіон Са + мепікват) виявився ефективнішим, ніж Терпал, 1,5 л/га (мепікват хлорид + етефон). 
Позакореневе застосування Мегафолу підвищувало врожайність пшениці сортів Смуглянка та Подолянка та знижувало негативну дію ретардантів на рослини пшениці у вегетаційних сезонах, які характеризувалися нестачею вологи. За результатами ICP-MS аналізів зразків рослин пшениці озимої сортів Смуглянка та Подолянка встановлено, що за умов вирощування пшениці на легких грунтах Полісся сучасні добрива з умістом амінокислот і композиційні ретарданти впливають на елементний склад рослин протягом вегетації, а також змінюють вміст неорганічних елементів у зерні. Озима м’яка пшениця середньорослого сорту Подолянка інтенсивного типу чутливіше реагувала на обробку ретардантами, ніж короткостебловий високоінтенсивний сорт Смуглянка. При цьому спостерігали підвищення вмісту елементів живлення у зерні озимої пшениці сорту Подолянка. Композиція ретардантів із похідним ацилциклогексадіону (Медакс Топ) також суттєво впливала на зміни елементів іоному, підвищуючи вміст Mg та інших елементів у рослинах і зерні. Позакореневе застосування композицій амінокислот одночасно з ретардантами може знижувати негативну дію РРР на формування врожаю за посухи та впливає на збереження складу неорганічних елементів під час вегетації та у зерні. Ці відмінності у реакції сортів пшениці озимої на дію ретардантів класу ацилциклогексадіонів та інших мають значення для уточнення систем живлення посівів культури в інтенсивних технологіях вирощування, зокрема, в умовах посухи та високих температур. Зменшення пулів ряду неорганічних елементів у рослинах (наприклад заліза) за дії ретардантів може бути пов'язане з обмеженнями надходження цих елементів із бідних грунтів Поліської зони та повинно компенсуватися позакореневим підживленням. Установлені особливості прояву активності регуляторів росту рослин свідчать про тісний зв’язок між сигнальними системами рослин та змінами іоному.

Ключові слова: пшениця; амінокислоти; ретарданти; ICP-MS; іоном

\section{Bступ}

«Зелена революція» суттєво підвищила рівні врожайності пшениці та інших зернових колосових культур у світі. Зростання виробництва високоякісного зерна залишається головним напрямом сучасного зерновиробництва та однією з основ високого рівня рентабельності рослинництва в Україні (Morgun et al., 2010, 2015; Reynolds, 2011, 2012). Проте зростаючі дози внесення мінеральних азотних добрив під високопродуктивні короткостеблові та середньорослі сорти пшениці часто вимагають застосування ретардантів для протидії виляганню посівів (Berry et al., 2004; Espindula et al., 2009; Morgun et al., 2010, 2015; Merry et al., 2015). Більшість сучасних ретардантів за механізмом дії належать до класу інгібіторів біосинтезу гіберелінів. Серед відомих із кінця 1970-х років РРР хлормекватхлорид (або хлорхоліну хлорид, чи 2-хлоро-N,N,N-триметилетанамінохлорид), мепікват (або 1,1-диметилпіперидину хлорид), який використовують у формі хлориду або пентаборату, хлорфоніум (або трибутил[(2,4-дихлорофеніл)метил]фосфонію) у формі хлориду, АМО-1618 (5-гідроксикарвакрил)триметиламонію хлорид 1-піперидину карбоксилат). Ці сполуки інгібують перетворення геранілгеранілпірофосфату до entкаурену. Наступне перетворення до ent-кауренату каталізується цитохром-Р-450 залежними монооксигеназами. Ретарданти наступного покоління на основі $\mathrm{N}$-гетероциклів: анцимідол ( $\alpha$-циклопропіл- $\alpha$-(4-метоксифеніл)-5-піримідинметанол, флурпримідол ( $\alpha$-(1-метилетил)- $\alpha$-[4-(трифлуорометокси)феніл]-5-піримідинметанол, тетцикласис (3aR,4R,4aS,6aR,7R,7aS)-rel-1-(4-хлорофеніл)3а,4,4a,6а,7,7а-гексагідро-4,7-метано-1Н-[1,2]-діазето-[3,4-f]-бензотриазол, паклобутразол $((\alpha \mathrm{R}, \beta \mathrm{R})-\mathrm{rel}-\beta-[(4$-хлорофеніл)метил]- $\alpha-$ (1,1-диметилетил)-1Н-1,2,4-триазол-1-етанол), уніконазол-Р ( $\beta \mathrm{E})-$

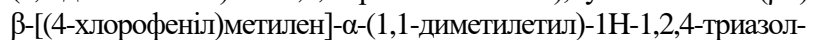
1-етанол та інабенфід N-[4-хлор-2-(гідроксифенілметил)феніл]-4піридинкарбоксамід інгібують ті самі ферменти утворення entкаурену та ent-кауренату. В останні десятиріччя ефективні ретарданти також знаходять серед похідних відомого раніше винайденою присутністю грамініцидів класу циклогексадіонів (ЦГД), зокрема - ацил-ЦГД, які ефективно блокують шляхи біосинтезу ГК, зменшують вміст активних гіберелінів $Г К_{1}$ і $Г К_{4}$ і широко використовуються у сучасному рослинництві (Evans, 1999; Matysiak, 2006). Ацил-ЦГД пригнічують фінальні стадії біосинтезу ГК, а саме гідроксилювання ГК 20 в ГК. Тринексапак-етил, прогексадіон-Са та дамінозид інгібують переважно $3 \beta$-гідроксилювання та утворення високоактивних гіберелінів із неактивних похідних (Rademacher, 2000; Morgun et al., 2010; Rademacher, 2010; Schwartau et al., 2013). Це підтверджується детальними дослідженнями механізму дії ацил-ЦГД (Evans, 1999), якими встановлено, що за структурою молекула прогексадіону подібна до 2-оксоглутарової кислоти (ко-субстрат деоксигеназ, що каталізують гідроксилювання пізніх стадій біосинтезу ГК). Тому первинним сайтом дії прогексадіону кальцію може бути саме $3 \beta$-гідроксилювання. У результаті застосування прогексадіону відбувається зниження рівня

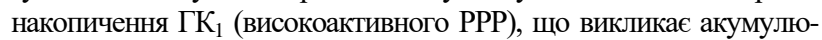
вання його попередника $-Г К_{20}$ (неактивної форми). При цьому на генетично близькому до пшениці та інших зернових колосових культур виді - куцоніжці двоколосковій (Brachypodium distachyon L. P. Beauv.) показано відсутність транскрипційної відповіді на дію фітогормонів, у тому числі прогександіону-Сa (Kakei et al., 2015).

Ретарданти класу похідних ацил-ЦГД легко засвоюються через листкову поверхню та переміщуються по рослині переважно акропетально, базипетальний рух обмежений. Вони можуть бути ефективними як за внесення у фазі кущіння, на початку виходу рослин у трубку, так і у фазі прапорцевого листка, коли активується ріст останнього підколосового міжвузля. Важливо, що у цей період усі елементи колоса вже закладені, тому внесення похідних ЦГД не має вираженого негативного впливу на продуктивність рослин (Morgun et al., 2010, 2015; Espindula, et al., 2009). Ця особливість прояву ретардантної активності нових РРР має значення щодо зменшення залежності технології вирощування зернових колосових культур від несприятливих умов вегетаційного сезону, зокрема дефіциту вологи, високих температур протягом другої половини вегетації. Саме несприятливі умови вегетаційних сезонів в останні роки часто знижують ефективність застосування ретардантів класу онієвих сполук, що на окремих сортах зернових культур спричиняє навіть зниження рівнів урожайності.

Механізм дії фітогормонів пов'язаний зі змінами вмісту неорганічних елементів у рослинах (Marschner, 1995; Chen et al., 1998; Bray et al., 2000; Battal et al., 2004; Marschner, 2012). ГК стимулює ріст і розвиток рослин, а саме проростання насіння, перехід із вегетативного до генеративного розвитку, від ювенільного до сформованого листка, визначає перебіг генеративної фази та розвиток зерна поряд із взаємодією різних факторів навколишнього середовища - світла, температури та вологи (Hedden, 2016). Також відомо про взаємозв'язок між проявом біологічної активності ГК і вмістом низки мікроелементів у рослинах, зокрема - заліза (Rademacher, 2000; Bray et al., 2000; Battal et al., 2004). Наприклад, установлено зміни вмісту іонів у рослинах за дії похідного ацил-ЦГД тринексапак-етилу на пшениці озимій (Virych et al., 2012).

При цьому інформація щодо впливу сучасних ретардантів, насамперед похідних ацил-ЦГД, на вміст біологічно важливих неорганічних елементів практично не досліджена. Інформація щодо змін іоному має значення для формування систем живлення культури для досягнення високих рівнів урожайності за внесення регуляторів росту рослин, у тому числі й за несприятливих грунтовокліматичних умов вирощування пшениці.

Суттєве обмеження щодо використання ретардантів у технологіях отримання високих врожаїв зернових колосових культур ïx інгібувальна дія на формування врожаю за дефіциту вологи та високих температур. Для похідних класу ацил-ЦГД ця залежність проявляться у дещо меншому ступені, порівняно 3 хлорхолінхлоридом або етефоном. 3 урахуванням можливості їх застосування у пізніші фази розвитку, у тому числі на початку генеративного розвитку, доцільна обробка ретардантами у композиціях одночасно 3 іншими агрохімікатами з метою досягнення синергічної або адитивної взаємодії. Раніше було показано, що застосування ад’ювантів посилює ретардантну активність хлормекват хлориду та прогексадіону-Са на посівах пшениці (Stachecki et al., 2004). Один із 
важливих щодо зниження фітотоксичної дії агрохімікатів складових отримання високих врожаїв - добрива з умістом амінокислот, зокрема Мегафол тощо, у позакореневому застосуванні (Morgun et al., 2010, 2015; Petrozza et al., 2014). Також застосування добрив 3 умістом амінокислот, на відміну від мінеральних добрив для позакореневого підживлення, можливе й за низьких рівнів дефіциту вологи, що, одночасно, може посилювати ретарданту дію РРР. При цьому зміни елементного складу рослин протягом вегетації за дії ретардантів і амінокислот можуть охарактеризувати взаємодію цих класів агрохімікатів, проте до цього часу вони не досліджені. Тому мета досліджень - з'ясувати вплив низки сучасних ретардантів - комплексів на основі похідного ацил-ЦГД та інших, композицій амінокислот, на прикладі Мегафолу, на накопичення деяких макро- та мікроелементів у рослинах високопродуктивних сортів пшениці озимої.

\section{Матеріал і методи досліджень}

Польові досліди проводили на сортах пшениці озимої (Triticum aestivum L.) Смуглянка та Подолянка на базі Дослідного сільськогосподарського виробництва Інституту фізіології рослин і генетики НАН України в смт Глеваха Васильківського району Київської області у вегетаційних сезонах 2015-2016 років. Ірунт темно-сірий опідзолений, піщано-суглинковий за механічним складом. Площа ділянки складала 12,95 м², облікової - 10,00 м². Повторність дослідних варіантів - 6-8-разова. Фон - $\mathrm{N}_{120} \mathrm{P}_{80} \mathrm{~K}_{140}$.

Виробничий дослід проводили у 2016 році на полях ТОВ «ПоділляЛатІнвест» (Тиврівський район Вінницької області).

Досліджували дію ретардантів прогексадіон $\mathrm{Ca}+$ мепікват хлорид (препарат Медакс Топ) та мепікват хлорид + етефон (Терпал), обидва виробництва BASF (Німеччина), які вносили одноразово навесні у фазу GS39 (Zadoks, 1974) у дозах 1,0 і 1,5 л/га відповідно; а також водорозчинного комплексу амінокислот, отриманих гідролізом водоростей - Мегафол, виробництва компанії Valagro, Італія. Протягом вегетації рослини обробляли фунгіцидами та інсектицидами, зокрема, у фазу кущіння, цвітіння та по прапорцевому листку. Проводили підживлення рослин і фенологічні спостереження.

Вміст білка та клейковини у зерні визначали на ІЧ-спектрометрі Inframatic 8600 (Perten Instruments, Швеція).

Визначення вмісту неорганічних елементів у зразках проводили на мас-спектрометрі з індуктивно зв'язаною плазмою ICPMS Agilent 7700x (Agilent Technologies, CШA) 3 ICP-MS Mass Hunter WorkStation (табл. 1). Зразки рослин пшениці озимої відбирали у фази початку цвітіння та повної стиглості. Зразки висушували до постійної маси, гомогенізували, наважку 0,400 г озолювали в азотній кислоті кваліфікації ICP-grade в мікрохвильовій системі пробопідготовки Milestone Start D (Milestone Inc., США). Після охолодження зразки розчиняли, коефіцієнт розведення - $250 \mathrm{X}$. Усі розчини готували на воді першого класу $\left(18 \mathrm{MOM}^{\cdot} \mathrm{cm}^{-1}\right)$, отриманій на системі очищення води Scholar-UV Nex Up 1000 (Human Corporation, Корея). Як зовнішній калібрувальний стандарт використовували робочі розчини ICP-MS Complete Standard IVICPMS-71A, а внутрішнього стандарту - 1 ppb Sc, обидва виробництва фірми Inorganic Ventures (США).

\section{Таблиця 1}

Основні налаштування мас-спектрометра Agilent 7700x для аналізу неорганічних елементів

\begin{tabular}{lcc}
\hline \multicolumn{1}{c}{ Показник } & Параметри & Значення \\
\hline Живлення & Потужність генератора, $\mathrm{W}$ & 1550 \\
\hline Налаштування & Потік газу-носія, л/хв. & 16,0 \\
аргонової плазми & Потік гелію, л/хв. & 0,2 \\
\hline & $\mathrm{CeO}^{+} / \mathrm{Ce}^{+}(\%)$ & 1,114 \\
Автоналаштування & $\mathrm{Ce}^{+} / \mathrm{Ce}^{+}(\%)$ & 1,867 \\
& Чутливість, імпульсів & $\mathrm{Li}(62700), \mathrm{Y}(92920)$, \\
& за секунду до мг/л & $\mathrm{Tl}(87080)$ \\
\hline
\end{tabular}

В аргоновій плазмі вибрані макро- та мікроелементи можуть утворювати хибні піки. Наприклад, рівні за масою $\mathrm{CaO}$ та ${ }^{56} \mathrm{Fe}$, чи
ArN або ArO з іншими ізотопами заліза. ArNH та KO можуть маскувати $\mathrm{Mn}, \mathrm{a} \mathrm{Ba}^{++}-\mathrm{Zn}$. Усі 6 ізотопів Са можуть взаємодіяти 3 $\mathrm{O}, \mathrm{H}$ та $\mathrm{Ar}$, що спричиняє неточності у визначенні $\mathrm{Cu}, \mathrm{Fe}, \mathrm{Sc}, \mathrm{Se}$. Хоча мідь добре іонізується в аргоновій плазмі (90\%), визначення ізотопу ${ }^{63} \mathrm{Cu}$ ускладнюється взаємодією $\mathrm{NaAr}$ та піками $\mathrm{P}, \mathrm{a}{ }^{65} \mathrm{Cu}$ перекривається $\mathrm{SO}_{2} / \mathrm{SO}_{2} \mathrm{H}$; також ізотопи міді інтерферують 3 оксидами кальцію та титану. Тому визначення проводили у режимі продування гелієм, що ефективно видаляє згадані матричні та елементні інтерференції.

Статистичні обрахунки проводили у програмному забезпеченні ICP-MS Mass Hunter WorkStation. Застосовували дисперсійний аналіз, відмінності між середніми значеннями вважали вірогідними за $\mathrm{P}<0,05$. У таблицях наведено середні арифметичні значення та їх стандартні похибки.

\section{Результати та їх обговорення}

Ефективність ретардантів на посівах пшениці озимої значною мірою залежить як від особливостей сорту, вмісту мінеральних поживних компонентів агрофітоценозу, так і від погодно-кліматичних умов. РРР можна застосовувати за дефіциту вологи з метою оптимізації водного балансу культурних рослин (Rokhafrooz, 2016). Проте у виробництві їх використання за несприятливих умов вирощування часто не сприяє підвищенню врожаїв зернових колосових культур.

Найважливіші кліматичні чинники, що впливають на довжину колоса, - температура повітря, тривалість фотоперіоду, наявність продуктивної вологи в метровому шарі грунту. Розвиток колоса у зернових прискорює тривалий фотоперіод і високі температури. За високої температури, що значно перевищувала $25^{\circ} \mathrm{C}$ у 2015 році, раніше сформувався верхівковий колосок і передчасно припинився його розвиток, у результаті чого колос утворився коротший. Із підвищенням температури вже $315^{\circ} \mathrm{C}$ до $25^{\circ} \mathrm{C}$ пришвидшується ріст зернівки, скорочується період від ії збільшення до повної стиглості, що спричиняє зниження врожаю. За недостатнього вологозабезпечення сформовані зерна також не розвиваються. Близький за рівнем високих температур і нестачі вологи також вегетаційний сезон 2016 року.

За несприятливих погодних умов сезонів 2015 і 2016 років (табл. 2) вилягання пшениці сортів Смуглянка та Подолянка у дослідах не спостерігали. Підвищення врожаю на короткостебловому сорті Смуглянка за внесення Терпалу не виявлено. Найвищих у досліді рівнів урожаю досягнуто за спільного внесення амінокислот і ретардантів. Спільна за внесення Мегафолу з Терпалом тенденція до зниження врожаю за внесення ретарданту на фоні короткотривалих посух не встановлено.

\section{Таблиця 2}

Вплив ретардантів та Мегафолу на врожайність пшениці озимої (т/га, ДСВ ІФРГ НАН України, Київська обл.)

\begin{tabular}{|c|c|c|c|c|}
\hline \multirow{2}{*}{ Варіанти } & \multicolumn{2}{|c|}{ Смуглянка } & \multicolumn{2}{|c|}{ Подолянка } \\
\hline & $2015 \mathrm{p}$. & $2016 \mathrm{p}$ & $2015 \mathrm{p}$. & $2016 \mathrm{p}$. \\
\hline Контроль & 7,35 & 8,11 & 7,09 & 7,55 \\
\hline Терпал, 1,0 л/га & 7,31 & 8,18 & 7,12 & 7,11 \\
\hline Медакс Топ, 1,0 л/га & 7,64 & 8,40 & 7,76 & 7,81 \\
\hline Мегафол, 1,5 л/т & 7,55 & 8,45 & 7,51 & 7,70 \\
\hline $\begin{array}{l}\text { Терпал, 1,0 л/га + } \\
\text { Мегафол, 1,5 л/га }\end{array}$ & 7,44 & 8,51 & 7,32 & 7,40 \\
\hline $\begin{array}{l}\text { Медакс Топ, } 1,0 \text { л/га + } \\
\text { Мегафол, 1,5 л/т }\end{array}$ & 7,75 & 8,48 & 7,51 & 7,90 \\
\hline $\mathrm{HIP}_{0,05}$ & 0,15 & 0,11 & 0,16 & 0,18 \\
\hline
\end{tabular}

Ця залежність спостерігалася й в умовах виробничого досліду у Вінницькій області. Ретардант Медакс Топ, як і у польових дослідах, виявився ефективнішим порівняно з Терпалом. В умовах вегетаційного сезону застосування ретардантів або не впливало на зростання врожаю (Терпал), або незначно підвищувало врожайність. При цьому спостерігали статистично достовірне зростання якісних показників зерна. Це, ймовірно, пов'язано 3 оптимізацією архітектоніки посіву та зростанням конкурентної здатності рослин пшениці відносно бур'янів, зокрема до метлюгу 
звичайного (Apera spica-venti L.), що протягом періоду після внесення ретардантів спостерігали візуально.

\section{Таблиця 3}

Вплив ретардантів на врожайність пшениці озимої сорту Актер (ТОВ «ПоділляЛатІнвест», Вінницька область, 2016)

\begin{tabular}{lcc}
\hline \multicolumn{1}{c}{ Варіанти } & Врожай, т/га & $\begin{array}{c}\text { Вміст } \\
\text { білка/клейковини, } \%\end{array}$ \\
\hline Контроль & 6,660 & $13,1 / 31,1$ \\
Терпал, 1,0 л/га & 6,649 & $13,9 / 31,8$ \\
Медакс Топ, 1,0 л/га $_{\text {HІР }_{0,05}}^{7,061}$ & $14,0 / 32,2$ \\
\hline
\end{tabular}

Без фонового обприскування грамініцидами лише на ділянках виробничого досліду, де вносили ретарданти, рослини метлюгу звичайного не піднімалися над посівом пшениці. Зростання якісних показників врожаю можливе також за посилення розвитку кореневої системи пшениці за дії ретардантів (Morgun et al., 2010, 2015).

Застосування ретардантів на озимій пшениці сорту Смуглянка слабко вплинуло на зниження висоти головного пагона (табл. 4). При цьому бічні пагони наближаються за довжиною до головних та візуально спостерігали суттєве вирівнювання посівів. Ретарданти (Терпал, Медакс Топ) слабко зменшували довжину четвертого міжвузля, орієнтовно до 20\%, і п'ятого - на 3-7\%. Застосування Мегафолу викликало вирівнювання стеблостою, при цьому спостерігали статистично достовірне посилення ретардантної активності. За внесення ретардантів шосте міжвузля не сформувалося, на відміну від варіанта із внесенням Мегафолу.

\section{Таблиця 4}

Вплив ретардантів і Мегафолу на біометричні показники головних пагонів рослин озимої пшениці сорту Смуглянка (ДСВ ІФРГ НАН України, 2015 р., $\mathrm{M} \pm \mathrm{m}, \mathrm{n}=30$ )

\begin{tabular}{|c|c|c|c|c|c|c|c|c|}
\hline \multirow{2}{*}{ Варіанти } & \multirow{2}{*}{$\begin{array}{l}\text { Кількість продук- } \\
\text { тивних пагонів, шт. }\end{array}$} & \multirow{2}{*}{$\begin{array}{c}\text { Висота продук- } \\
\text { тивних пагонів, см }\end{array}$} & \multicolumn{6}{|c|}{ Довжина міжвузлів, см } \\
\hline & & & 1 & 2 & 3 & 4 & 5 & 6 \\
\hline Контроль & $3,4 \pm 0,5$ & $92,4 \pm 7,6$ & $6,0 \pm 1,8$ & $8,7 \pm 2,5$ & $16,9 \pm 4,0$ & $29,1 \pm 4,1$ & $35,1 \pm 4,3$ & - \\
\hline Терпал, 1,5 л/га & $3,2 \pm 0,4$ & $86,6 \pm 2,9$ & $6,2 \pm 1,8$ & $9,1 \pm 2,3$ & $11,9 \pm 2,7$ & $20,5 \pm 3,5^{*}$ & $32,6 \pm 3,1$ & - \\
\hline Медакс Топ, 1,0 л/га & $3,4 \pm 0,7$ & $86,3 \pm 6,9$ & $6,1 \pm 2,2$ & $8,5 \pm 2,5$ & $12,8 \pm 3,5$ & $22,1 \pm 6,4$ & $33,6 \pm 2,4$ & - \\
\hline Мегафол, 1,5 л/га & $3,2 \pm 0,4$ & $99,1 \pm 2,6$ & $6,3 \pm 2,6$ & $9,5 \pm 2,4$ & $15,1 \pm 0,9$ & $29,9 \pm 3,5$ & $34,5 \pm 5,9$ & $28,3 \pm 4,6$ \\
\hline Терпал, 1,5 л/га + Мегафол, 1,5 л/га & $3,0 \pm 0,4$ & $85,3 \pm 2,4$ & $4,6 \pm 1,5$ & $8,0 \pm 1,5$ & $13,1 \pm 3,5$ & $21,4 \pm 3,8^{*}$ & $35,2 \pm 1,9$ & - \\
\hline Медакс Топ, 1,0 л/га + Мегафол, 1,5 л/га & $3,2 \pm 0,4$ & $83,7 \pm 3,8$ & $5,2 \pm 2,1$ & $7,7 \pm 3,3$ & $13,7 \pm 4,3$ & $21,1 \pm 3,4^{*}$ & $35,0 \pm 3,2$ & - \\
\hline
\end{tabular}

Примітка: * - тут і в наступних таблицях відмінності показників щодо контролю вірогідні за $\mathrm{P}<0,05$.

\section{Таблиця 5}

Вплив ретардантів і Мегафолу на біометричні показники головних пагонів рослин озимої пшениці сорту Подолянка (ДСВ ІФРГ НАН України, 2015 p., $\mathrm{M} \pm \mathrm{m}, \mathrm{n}=30$ )

\begin{tabular}{|c|c|c|c|c|c|c|c|}
\hline \multirow{2}{*}{ Варіанти } & \multirow{2}{*}{$\begin{array}{c}\text { Кількість продуктив- } \\
\text { них пагагонів, шт. }\end{array}$} & \multirow{2}{*}{$\begin{array}{c}\text { Висота продуктив- } \\
\text { них пагонів, см }\end{array}$} & \multicolumn{5}{|c|}{ Довжина міжвузлів, см } \\
\hline & & & 1 & 2 & 3 & 4 & 5 \\
\hline Контроль & $3,2 \pm 0,4$ & $103,9 \pm 4,4$ & $6,1 \pm 2,2$ & $10,9 \pm 2,7$ & $16,5 \pm 4,2$ & $28,0 \pm 4,5$ & $37,6 \pm 2,1$ \\
\hline Терпал, 1,5 л/га & $3,4 \pm 0,5$ & $99,3 \pm 6,3$ & $6,2 \pm 3,1$ & $11,3 \pm 3,2$ & $14,8 \pm 3,9$ & $22,1 \pm 6,3^{*}$ & $32,7 \pm 5,1^{*}$ \\
\hline Медакс Топ, 1,0 л/га & $3,2 \pm 0,5$ & $92,3 \pm 6,5^{*}$ & $4,3 \pm 2,3$ & $9,9 \pm 3,0$ & $16,7 \pm 4,8$ & $27,3 \pm 8,2$ & $36,3 \pm 1,9$ \\
\hline Мегафол, 1,5 л/га & $3,3 \pm 0,5$ & $102,1 \pm 6,6$ & $5,1 \pm 1,4$ & $11,2 \pm 1,5$ & $17,7 \pm 4,3$ & $28,6 \pm 4,7$ & $37,0 \pm 1,4$ \\
\hline Терпал, 1,5 л/га + Мегафол, 1,5 л/га & $3,3 \pm 0,7$ & $97,7 \pm 4,2$ & $4,7 \pm 0,9$ & $9,6 \pm 1,4$ & $13,5 \pm 1,7^{*}$ & $22,9 \pm 1,8^{*}$ & $38,4 \pm 3,3$ \\
\hline Медакс Топ, 1,0 л/га + Мегафол, 1,5 л/га & $3,4 \pm 0,5$ & $95,5 \pm 7,0$ & $4,4 \pm 3,1$ & $9,8 \pm 3,2$ & $14,3 \pm 4,2$ & $25,2 \pm 7,4$ & $36,6 \pm 5,6$ \\
\hline
\end{tabular}

Застосування ретардантів на сорті Подолянка викликало деяке зменшення висоти рослин, порівняно $з$ контролем (табл. 5). Обробка рослин прогексадіоном Са і мепікватом знижувало довжину стебла на $11,2 \%$, тоді як Терпалом, 1,5 л/га - на 3,9\%. Проте найвищий рівень скорочення третього - п'ятого міжвузлів виявлено на варіантах із Терпалом. Застосування на посівах озимої пшениці композиції ретардантів із Мегафолом теж сприяло зниженню висоти рослин, особливо за рахунок третього - четвертого міжвузлів.

Короткостебловий сорт пшениці озимої Смуглянка характеризується високими рівнями реутилізації пластичних речовин у другу половину вегетації (Mogun et al., 2010, 2015). Тому, на відміну від варіантів із сортом Подолянка, за внесення Мегафолу на короткостебловому сорті сформувалося шосте міжвузля.

Таким чином, в умовах виробничого та польових дослідів застосування ретарданту Медакс Топ суттєво переважало за ефективністю Терпал, внесення якого, переважно, не викликало підвищення врожаю у вегетаційних сезонах 2015 та 2016 років. Ефективність застосування Мегафолу була дещо вищою на середньорослому сорті Подолянка. Застосування Мегафолу з Терпалом у композиції підвищувало ефективність останнього щодо впливу на рівень урожаю пшениці.

Велика кількість іонів металів входить до складу низки білкових молекул як коферментів, кофакторів або простетичних груп. Частина 3 них проявляє властивості універсальних вторинних посередників $\left(\mathrm{Ca}^{2+}\right)$, формує електрохімічні градієнти мембран $\left(\mathrm{K}^{+}\right.$, $\left.\mathrm{Na}^{+}\right), \epsilon$ одними 3 важливих елементів перебігу енергетичних $\mathrm{i}$ пластичних процесів $\left(\mathrm{Mg}^{2+}\right)$. Зміни іоному рослин генетично детерміновані (Pokhylko et al., 2016), можуть залежати від дії агрохімікатів (Kabata-Pendias et al., 1989). Застосування ретардантів - елемент технологій високих врожаїв і не розглядасться без відповідних рівнів фону азотного живлення посівів пшениці (Shekoofa, 2008). Є відомості про взаємозв'язок між рівнем сірчаного живлення та впливом ретардантів на показники врожаю пшениці ярої (Hussain, 2007). При цьому інформація щодо напрямку змін має значення для формування високоефективних систем живлення посівів.

Обробка рослин ретардантами та амінокислотами впливала на зміни вмісту неорганічних елементів. Мепікват хлорид + етефон (Терпал, 1,5 л/га) окремо й у композиції з Мегафолом, 1,5 л/га підвищував накопичення калію листками пшениці озимої сорту Подолянка порівняно з контролем. У листках озимої пшениці сорту Смуглянка збільшення калію відбувалося лише за умови обробки сумішшю прогексадіону з мепікват хлоридом (Медакс Топ, 1,0 л/га) і комплексом амінокислот (Мегафол, 1,5 л/га) (табл. 6). Зростання вмісту калію, ймовірно, може бути зумовлене дією амінокислот, які входять до складу Мегафолу та стимулюють метаболічні процеси та засвоєння поживних речовин рослиною. При цьому вірогідна інтенсифікація процесів поглинання та транспорту К, який бере участь у біосинтезі целюлоз і геміцелюлоз, сприяє потовщенню клітинних стінок соломини злакових, підвищуючи їх стійкість до вилягання (Morgun et al., 2010, 2015). Пул калію у листках рослин сорту Подолянка на контрольному варіанті був дещо вищим за вміст елемента в листках рослин сорту Смуглянка, що збігається з відомою вищою посухостійкістю пшениці сорту Подолянка (Morgun et al., 2010, 2015).

Тенденція зниження пулу калію за дії ретардантів може мати негативний вплив в умовах посухи та високих температур. При цьому сортові відмінності накопичення основного неорганічного осмотичного чинника у клітинах, ймовірно, можуть бути викорис- 
тані під час розроблення експрес-аналізів високопродуктивних сортів пшениці озимої на дію похідних ЦГД за дії посухи та високих температур. У попередні роки в умовах виробництва у східних регіонах України в умовах посухи протягом генеративного періоду розвитку пшениці спостерігали ушкодження рослин за внесення препаратів класу стробілуринів. Розгляд механізмів прояву ушкоджень сфокусований на дефіциті калію у надземних частинах рослин, навіть за високих рівнів вмісту елемента в грунтах. Використання біостимуляторів, насамперед гідролізатів амінокислот, може спричинити зростання пулу калію в надземних органах рослин протягом вегетації (Saa et al., 2015). Підсумовуючи власні та літературні дані, можна стверджувати, що позакореневе застосування амінокислот - перспективний елемент технологій позакореневого живлення зернових культур, особливо за дефіциту вологи протягом вегетаційного періоду.

\section{Таблиця 6}

Вплив ретардантів Терпал і Медакс Топ і Мегафолу на накопичення макроелементів у прапорцевих листках рослин пшениці озимої (г/кг, $\mathrm{M} \pm \mathrm{m}, \mathrm{n}=12)$

\begin{tabular}{|c|c|c|c|c|c|c|}
\hline \multirow{2}{*}{ Варіанти } & \multicolumn{3}{|c|}{ Смуглянка } & \multicolumn{3}{|c|}{ Подолянка } \\
\hline & $\mathrm{Mg}$ & $\mathrm{K}$ & $\mathrm{Ca}$ & $\mathrm{Mg}$ & $\mathrm{K}$ & $\mathrm{Ca}$ \\
\hline Контроль & $2,35 \pm 0,12$ & $24,54 \pm 1,23$ & $0,87 \pm 0,04$ & $1,64 \pm 0,08$ & $25,19 \pm 1,26$ & $0,78 \pm 0,04$ \\
\hline Терпал, 1,5 л/га & $2,53 \pm 0,13$ & $22,59 \pm 1,13$ & $0,73 \pm 0,03$ & $2,29 \pm 0,11^{*}$ & $26,24 \pm 1,31$ & $0,80 \pm 0,04$ \\
\hline Медакс Топ, 1,0 л/га & $3,12 \pm 0,16^{*}$ & $19,32 \pm 0,96^{*}$ & $0,94 \pm 0,05^{*}$ & $2,85 \pm 0,14^{*}$ & $21,13 \pm 1,06^{*}$ & $0,94 \pm 0,05^{*}$ \\
\hline Мегафол, 1,5 л/га & $2,35 \pm 0,12$ & $24,88 \pm 1,04$ & $0,85 \pm 0,04$ & $2,20 \pm 0,11^{*}$ & $29,89 \pm 1,49 *$ & $0,70 \pm 0,03$ \\
\hline Терпал, 1,5 л/га + Мегафол, 1,5 л/га & $2,37 \pm 0,10$ & $22,61 \pm 1,13$ & $0,66 \pm 0,03^{*}$ & $2,51 \pm 0,12^{*}$ & $26,92 \pm 1,35$ & $0,76 \pm 0,04$ \\
\hline Медакс, 1,0 л/га + Мегафол Топ, 1,5 л/га & $2,95 \pm 0,10^{*}$ & $27,75 \pm 1,39 *$ & $0,60 \pm 0,03^{*}$ & $2,74 \pm 0,12^{*}$ & $25,29 \pm 1,26$ & $0,66 \pm 0,03^{*}$ \\
\hline
\end{tabular}

Вміст кальцію в листках пшениці обох сортів дещо підвищувався за обробки препаратом Медакс Топ. У сорту Подолянка вміст кальцію дещо збільшується ще й у варіанті із застосуванням Терпалу. Мікроелементи - невід'ємна частина живлення рослин, без яких неможливий розвиток рослин і формування врожаю. Вони необхідні для життєдіяльності рослин, їх не можна замінити ніякими іншими речовинами. Кількість мікроелементів, необхідних для рослин, відносно невелика, порівняно з кількістю необхідних для них макроелементів. Але навіть невеликий дефіцит цих речовин може викликати захворювання, неможливість засвоєння основних мікроелементів живлення та навіть загибель рослин.

Обробка мепікват хлоридом з етефоном (Терпал) підвищувала вміст марганцю та міді у прапорцевих листках рослин озимої пшениці сорту Подолянка на 13,0\% і 44,0\% відповідно, тоді як прогексадіон Са з мепікват хлоридом (Медакс Топ) сприяв накопиченню

марганцю та цинку на 14,0\% і 18,0\% більше, порівняно з контролем (табл. 7). Композиція Терпал + Мегафол сприяла зростанню вмісту Mn на 16,9\%, тоді як цинку - на 12,8\%. Цей сорт пшениці краще накопичував у прапорцевих листках і мідь майже в усіх варіантах, за винятком варіанта з Медакс Топ + Мегафол. У сорту Смуглянка збільшувався лише вміст цинку в усіх варіантах обробки, за винятком (як і в сорту Подолянка) поєднання Медакс Топ + Мегафол. Усі варіанти обробки рослин пшениці сорту Смуглянка спричинили зниження вмісту марганцю в іiі листках. Разом із цим, зазначимо також зниження вмісту заліза в обох сортів пшениці.

У зерні сорту Смуглянка вміст калію дещо зростав у варіанті 3 обробкою сумішшю мепікват хлориду з етефоном (Терпалом) на $3,8 \%$, тоді як у сорту Подолянка за такої ж обробки він був на 46,8\% вищим, ніж у контролі (табл. 8). Усі інші варіанти обробки рослин сприяли значному накопиченню в зерні як калію, так і магнію.

\section{Таблиця 7}

Вплив ретардантів Терпал і Медакс Топ і Мегафолу на накопичення мікроелементів у прапорцевих листках рослин пшениці озимої (мг/кг, $\mathrm{M} \pm \mathrm{m}, \mathrm{n}=12$ )

\begin{tabular}{|c|c|c|c|c|c|c|c|c|}
\hline \multirow{2}{*}{ Варіанти } & \multicolumn{4}{|c|}{ Смуглянка } & \multicolumn{4}{|c|}{ Подолянка } \\
\hline & $\mathrm{Mn}$ & $\mathrm{Fe}$ & $\mathrm{Cu}$ & $\mathrm{Zn}$ & $\mathrm{Mn}$ & $\mathrm{Fe}$ & $\mathrm{Cu}$ & $\mathrm{Zn}$ \\
\hline Контроль & $159 \pm 8$ & $150 \pm 8$ & $4,3 \pm 0,2$ & $11,6 \pm 0,6$ & $103 \pm 5$ & $94 \pm 5$ & $3,7 \pm 0,2$ & $11,9 \pm 0,6$ \\
\hline Терпал, 1,5 л/га & $105 \pm 5^{*}$ & $114 \pm 6^{*}$ & $3,5 \pm 0,2 *$ & $13,5 \pm 0,8$ & $149 \pm 8^{*}$ & $76 \pm 4^{*}$ & $5,4 \pm 0,3 *$ & $10,9 \pm 0,5$ \\
\hline Медакс Топ, 1,0 л/га & $122 \pm 6^{*}$ & $113 \pm 6^{*}$ & $3,2 \pm 0,2^{*}$ & $13,9 \pm 0,8$ & $118 \pm 6^{*}$ & $72 \pm 4^{*}$ & $4,3 \pm 0,3^{*}$ & $14,0 \pm 0,7^{*}$ \\
\hline Мегафол, 1,5 л/га & $127 \pm 6^{*}$ & $114 \pm 6^{*}$ & $4,9 \pm 0,2^{*}$ & $14,7 \pm 0,7^{*}$ & $101 \pm 4$ & $79 \pm 4^{*}$ & $4,9 \pm 0,2$ & $16,0 \pm 0,8^{*}$ \\
\hline Терпал, 1,5 л/га + Мегафол Топ, 1,5 л/га & $116 \pm 6^{*}$ & $95 \pm 5^{*}$ & $4,4 \pm 0,2$ & $14,0 \pm 0,6^{*}$ & $142 \pm 6^{*}$ & $75 \pm 4^{*}$ & $4,0 \pm 0,2$ & $15,3 \pm 0,5^{*}$ \\
\hline Медакс Топ, 1,0 л/га + Мегафол, 1,5 л/га & $95 \pm 5^{*}$ & $89 \pm 4 *$ & $4,5 \pm 0,2$ & $14,4 \pm 0,6^{*}$ & $121 \pm 5^{*}$ & $63 \pm 3^{*}$ & $3,1 \pm 0,1$ & $15,8 \pm 0,5^{*}$ \\
\hline
\end{tabular}

\section{Таблиця 8}

Вплив ретардантів Терпал і Медакс Топ і Мегафолу на накопичення макроелементів у зерні пшениці озимої (г/кг, $\mathrm{M} \pm \mathrm{m}, \mathrm{n}=15)$

\begin{tabular}{|c|c|c|c|c|c|c|}
\hline \multirow{2}{*}{ Варіанти } & \multicolumn{3}{|c|}{ Смуглянка } & \multicolumn{3}{|c|}{ Подолянка } \\
\hline & $\mathrm{Mg}$ & $\mathrm{K}$ & $\mathrm{Ca}$ & $\mathrm{Mg}$ & $\mathrm{K}$ & $\mathrm{Ca}$ \\
\hline Контроль & $0,95 \pm 0,05$ & $4,10 \pm 0,20$ & $0,03 \pm 0,002$ & $0,60 \pm 0,03$ & $2,78 \pm 0,14$ & $0,02 \pm 0,001$ \\
\hline Терпал, 1,5 л/га & $0,89 \pm 0,04$ & $4,26 \pm 0,21$ & $0,04 \pm 0,002$ & $0,92 \pm 0,05^{*}$ & $4,08 \pm 0,20 *$ & $0,04 \pm 0,002$ \\
\hline Медакс Топ, 1,0 л/га & $0,91 \pm 0,04$ & $4,01 \pm 0,20$ & $0,04 \pm 0,002$ & $0,95 \pm 0,05^{*}$ & $3,88 \pm 0,19 *$ & $0,04 \pm 0,002$ \\
\hline Мегафол, 1,5 л/га & $0,92 \pm 0,05$ & $4,29 \pm 0,21$ & $0,04 \pm 0,002$ & $0,93 \pm 0,05^{*}$ & $3,75 \pm 0,19^{*}$ & $0,03 \pm 0,002$ \\
\hline Терпал, 1,5 л/га + Мегафол, 1,5 л/га & $0,96 \pm 0,05$ & $3,92 \pm 0,20$ & $0,03 \pm 0,002$ & $0,83 \pm 0,04^{*}$ & $3,76 \pm 0,19 *$ & $0,03 \pm 0,002$ \\
\hline Медакс Топ, 1,0 л/га + Мегафол, 1,5 л/га & $0,93 \pm 0,05$ & $3,92 \pm 0,20$ & $0,03 \pm 0,001$ & $0,88 \pm 0,04^{*}$ & $3,51 \pm 0,18^{*}$ & $0,02 \pm 0,001$ \\
\hline
\end{tabular}

Вміст кальцію у зерні сорту Подолянка досить високий у всіх варіантах обробки рослин, тоді як у зерні сорту Смуглянка він збілышувався за обробки мепікват хлоридом з етефоном (Терпал) $\mathrm{i}$ прогексадіон Са з мепікват хлоридом (Медакс Топ). Необхідно зазначити, що зерно пшениці сорту Смуглянка в контрольному ва- ріанті містило значно вищий пул макро- та мікроелементів, ніж зерно сорту Подолянка. Достатня кількість Мn - необхідна умова нормального фізіологічного розвитку рослин і отримання високих врожаїв. Уміст у зерні марганцю, як одного з необхідних для людини мікроелементів, - важливий показник якості зерна. Накопи- 
чення Mn рослиною зумовлене не тільки факторами, які впливають на його кількість і доступність для рослин у грунті, а й ефективністю поглинання мікроелемента рослиною (Marschner, 1995).

Обробка регуляторами росту (Терпал, Медакс Топ) викликала підвищення вмісту марганцю на 3,0-5,4\% у сорту Смуглянка і на 54,9-60,4\% - у сорту Подолянка порівняно з контролем. Вміст цин- ку в зерні зростав у всіх варіантах обробки рослин, в обох сортів пшениці, але білыше виражений - на сорті Подолянка (табл. 9). Комбінація діючих речовин прогексадіон Са з мепікват хлоридом (Медакс Топ) зумовлювала підвищення майже удвічі вмісту міді в зерні озимої пшениці, проте це не перевищило гранично допустимі межі цього елемента (за DSTU 3768-2010 10 мг/кг).

Таблиця 9

Вплив ретардантів Терпал і Медакс Топ і Мегафолу на накопичення мікроелементів у зерні пшениці озимої (мг/кг, $\mathrm{M} \pm \mathrm{m}, \mathrm{n}=15)$

\begin{tabular}{|c|c|c|c|c|c|c|c|c|}
\hline \multirow{2}{*}{ Варіанти } & \multicolumn{4}{|c|}{ Смуглянка } & \multicolumn{4}{|c|}{ Подолянка } \\
\hline & $\mathrm{Mn}$ & $\mathrm{Fe}$ & $\mathrm{Cu}$ & $\mathrm{Zn}$ & $\mathrm{Mn}$ & $\mathrm{Fe}$ & $\mathrm{Cu}$ & $\mathrm{Zn}$ \\
\hline Контроль & $36,9 \pm 1,9$ & $37,7 \pm 1,9$ & $1,8 \pm 0,1$ & $13,6 \pm 0,7$ & $24,3 \pm 1,2$ & $21,1 \pm 1,1$ & $1,4 \pm 0,1$ & $8,5 \pm 0,4$ \\
\hline Терпал, 1,5 л/га & $38,1 \pm 1,9$ & $29,4 \pm 1,5$ & $1,7 \pm 0,1$ & $18,4 \pm 0,9 *$ & $37,7 \pm 1,9 *$ & $33,1 \pm 1,7^{*}$ & $2,1 \pm 0,1^{*}$ & $14,6 \pm 0,7^{*}$ \\
\hline Медакс Топ, 1,0 л/га & $38,9 \pm 1,9$ & $32,5 \pm 1,6$ & $2,8 \pm 0,2^{*}$ & $14,2 \pm 0,7$ & $39,0 \pm 2,0 *$ & $36,0 \pm 1,8^{*}$ & $2,3 \pm 0,1^{*}$ & $12,6 \pm 0,6^{*}$ \\
\hline Мегафол, 1,5 л/га & $45,5 \pm 2,3^{*}$ & $34,8 \pm 1,7$ & $2,0 \pm 0,1$ & $19,4 \pm 1,0^{*}$ & $41,5 \pm 2,1^{*}$ & $36,1 \pm 1,8^{*}$ & $2,1 \pm 0,1^{*}$ & $14,8 \pm 0,7^{*}$ \\
\hline Терпал, 1,5 л/га + Мегафол, 1,5 л/га & $43,2 \pm 1,7 *$ & $34,3 \pm 1,7$ & $2,1 \pm 0,1^{*}$ & $18,9 \pm 0,7^{*}$ & $35,3 \pm 1,8^{*}$ & $31,1 \pm 1,6^{*}$ & $1,9 \pm 0,1^{*}$ & $13,1 \pm 0,7^{*}$ \\
\hline Медакс Топ, 1,0 л/га + Мегафол, 1,5 л/га & $46,1 \pm 1,8^{*}$ & $32,7 \pm 1,6$ & $2,6 \pm 0,1^{*}$ & $16,3 \pm 0,8^{*}$ & $33,7 \pm 1,7 *$ & $33,3 \pm 1,7^{*}$ & $2,0 \pm 0,1^{*}$ & $12,2 \pm 0,6^{*}$ \\
\hline
\end{tabular}

Отже, застосування Мегафолу та регуляторів росту на пшениці озимій сорту Подолянка позитивно впливало на накопичення як калію, магнію та кальцію, так і марганцю, заліза, міді та цинку в зерні. Таким чином, озима м'яка пшениця сорту Подолянка, яка належить до середньостеблового, інтенсивного типу, більш чутливо реагувала на обробку амінокислотами та ретардантами підвищенням вмісту елементів у зерні, ніж короткостебловий високоінтенсивний сорт Смуглянка. Необхідно зазначити, що зерно пшениці високопродуктивного сорту Смуглянка на контролі містило значно вищий пул макро- та мікроелементів, ніж зерно середньорослого сорту Подолянка.

\section{Висновки}

В умовах польових та виробничого дослідів вегетаційних сезонів 2015-2016 pр. на посівах високопродуктивних сортів пшениці озимої ретардант Медакс Топ, 1,0 л/га (прогексадіон Са + мепікват хлорид) виявився ефективнішим, ніж Терпал, 1,5 л/га (мепікват хлорид + етефон). Позакореневе застосування Мегафолу сприяло підвищенню врожайності пшениці озимої сортів Смуглянка та Подолянка та знижувало від'ємну дію ретардантів на рослини пшениці у вегетаційних сезонах, які характеризувалися нестачею вологи. За результатами визначення вмісту неорганічних елементів методом мас-спектрометрії у зразках рослин пшениці озимої сортів Смуглянка та Подолянка показано, що в умовах вирощування пшениці на легких грунтах Полісся сучасні композиційні ретарданти впливають на елементний склад рослин протягом вегетації, а також змінюють вміст неорганічних елементів у зерні.

Озима м'яка пшениця середньорослого сорту Подолянка інтенсивного типу чутливіше реагувала на обробку амінокислотами та ретардантами, ніж короткостебловий високоінтенсивний сорт Смуглянка. При цьому спостерігали підвищення вмісту елементів живлення в зерні озимої пшениці сорту Подолянка. Варто зазначити, що зерно пшениці сорту Смуглянка на контрольному варіанті містило вищий пул макро- та мікроелементів, ніж зерно сорту Подолянка.

Обробка рослин пшениці озимої сорту Подолянка мепікват хлоридом і етефоном (Терпал, 1,5 л/га) позитивно впливала на накопичення як калію, магнію та кальцію, так і марганцю, заліза, міді та цинку в зерні. Композиція ретардантів з умістом похідного ЦГД (Медакс Топ) також суттєво впливала на зміни вмісту неорганічних елементів у рослинах і у зерні. Зазначимо суттєве зростання вмісту магнію в листках і у зерні за дії препарату Медакс Топ. Зростання вмісту магнію у прапорцевих листках збігалося 3 показаним раніше зростанням вмісту хлорофілу.

Протягом досліджень у вегетаційних сезонах 2015-2016 років періодичні посухи були найбільш значущим абіотичним стресом, що обмежували ріст і продуктивність посівів пшениці. Позакореневе застосування композицій амінокислот одночасно з ретардантами може знижувати інгібувальну дію РРР на формування врожаю в умовах посухи та впливає на збереження складу неорганічних елементів протягом вегетації та у зерні.
Такі відмінності у реакції сортів пшениці озимої на дію сучасних ретардантів мають значення для уточнення систем живлення посівів культури в інтенсивних технологіях вирощування, зокрема, в умовах посухи та високих температур. Зменшення пулів ряду неорганічних елементів у рослинах за дії ретардантів, наприклад, заліза, ймовірно пов'язане з обмеженнями надходження цих елементів із бідних грунтів Поліської зони та повинно компенсовуватися позакореневим підживленням. Установлені особливості прояву активності регуляторів росту рослин свідчать про тісний зв'язок між сигнальними системами рослин та змінами іоному.

Внесення ретардантів Медакс Топ, 1,0 л/га (прогексадіон Са + мепікват хлорид) та Терпалу, 1,5 л/га (мепікват хлорид + етефон) запорука високих врожаїв на посівах високопродуктивних короткостеблового сорту Смуглянка та середньорослого Подолянка, а застосування ретардантів у композиціях із добривами з умістом амінокислот (Мегафол).

\section{References}

Battal, P. (2004). Effects of some mineral nutrients on gibberellic acid levels in maize plants (Zea mays L.). Economic Botany, 58, 195.

Berry, P. M., Sterling, M., Spink, J. H., Baker, C. J., Bradley, S. R., Mooney, S. J., Tams, A. R., \& Ennos, A. R. (2004). Understanding and reducing lodging in cereals. Advances in Agronomy, 84, 217-271.

Bray, E. A., Bailey-Serres, J., \& Weretilnyk, E. (2000). Responses to abiotic stresses. Gruissem, W. et al. (eds.), Biochemistry and Molecular Biology of Plants. American Society of Plant Physiologists, Rockville, MD, 1158-1249.

Chen, J.-G., Cheng, S.-H., Cao, W., \& Zhou, X. (1998). Involvement of endogenous plant hormones in the effect of mixed nitrogen source on growth and tillering of wheat. Journal of Plant Nutrition, 21(1), 87-97.

Espindula, M. C., Rocha, V. S., Grossi, J. A. S., Souza, M. A., Souza, L. T., \& Favarato, L. F. (2009). Use of growth retardants in wheat. Planta Daninha, 27(2), 379-387.

Evans, J. R., Evans, R. R., Regusci, C. L., \& Rademacher, W. (1999). Mode of action, metabolism, and uptake of BAS $125 \mathrm{~W}$, prohexadione-calcium. HortScience, 34(7), 1200-1201.

Hedden, P., \& Stephen, G. T. (2016). Annual plant reviews. The Gibberellins. John Wiley \& Sons. March, 11.

Hussain, Z., \& Leitch, M. H. (2007). The effect of sulphur and growth regulators on growth characteristics and grain yield of spring sown wheat. Journal of Plant Nutrition, 30, 67-77.

Kabata-Pendias, A., \& Pendias, H. (1989). Mikroyelementy v pochvah i rasteniyah [Microelements in soils and plants]. Mir, Moscow (in Russian).

Kakei, Y., Mochida, K., Sakurai, T., Yoshida, T., Shinozaki, K., \& Shimada, Y. (2015). Transcriptome analysis of hormone-induced gene expression in Brachypodium distachyon. Scientific Reports, 5, 14476.

Marschner, H. (1995). Mineral nutrition of higher plants. Academic Press, London.

Marschner, P. (2012). Marschner’s mineral nutrition of higher plants. Academic Press, 3d ed.

Matysiak, K. (2006). Influence of trinexapac-ethyl on growth and development of winter wheat. Journal of Plant Protection Research, 46(2), 133-143.

Merry, A. M., Carew, A. L., Leith, P., Nelson, R., \& Acuna, T. B. (2015). Agronomist use of PGR - A survey. Agricultural Science, 27(2), 24-32.

Morgun, V. V., Sanin, Y. V., \& Schwartau, V. V. (2015). Klub 100 centneriv. Suchasni sorty ta optimal'ni sistemi zhivlennya j zahistu ozimoyi pshenyci 
[Club 100 centners. Modern varieties and optimal systems of nutrition and protection of winter wheat]. Logos, Kyiv (in Ukrainian).

Morgun, V. V., Schwartau, V. V., \& Kiriziy, D. A. (2010). Fiziologicheskie osnovy formirovaniya vysokoj produktivnosti zernovyh zlakov [Physiological bases of forming of the high productivity of cereals]. Fiziologia i Biohimiya Kulturnyh Rasteniy, 42(5), 374-392 (in Russian).

Petrozza, A., Santaniello, A., Summerer, S., Di Tommaso, G., Di Tommaso, D., Paparelli, E., Piaggesi, A., Perata, P., \& Cellini, F. (2014). Physiological responses to Megafol $(\mathrm{R})$ treatments in tomato plants under drought stress: A phenomic and molecular approach. Scientia Horticulturae, 174(1), 185-192.

Pokhylko, S. Y., Schwartau, V. V., Mykhalska, L. M., Dugan, O. V., \& Morgun, B. V. (2016). ICP-MS analysis of bread wheat carrying the GPC-B1gene of Triticum turgidum ssp. dicoccoides. Biotechnologia Acta, 9(5), 64-69.

Rademacher, W. (2000). Growth retardants: Effects on gibberellin biosynthesis and other metabolic pathways. Annual Review of Plant Physiology and Plant Molecular Biology, 51, 501-531.

Rademacher, W. (2010). Control of lodging in intense european cereal production. Plant Growth Regulation Society of America.

Reynolds, M., Bonnett, D., Chapman, S. C., Furbank, R. T., Manes, Y., Mather, D. E., \& Parry, M. A. J. (2011). Raising yield potential of wheat. I. Overview of a consortium approach and breeding strategies. Journal of Experimental Botany, 62, 439-452.

Reynolds, M., Foulkes, J., Furbank, R., Griffiths, S., King, J., Murchie, E., \& Slafer, G. (2012). Achieving yield gains in wheat. Plant, Cell and Environment, 35, 1799-1823.

Rokhafrooz, K., Emam, Y., \& Pirasteh-Anosheh, H. (2016) The effect of chlormequat chloride on yield and yield components of three wheat cultivars under drought stress conditions. Journal of Crop Production and Processing, 6(20), 111-123.

Saa, S., Olivos-Del Rio, A., Castro, S., \& Brown, P. H. (2015). Foliar application of microbial and plant based biostimulants increases growth and potassium uptake in almond (Prunus dulcis [Mill.] D. A. Webb). Frontiers in Plant Science, 23(6), 87.

Schwartau, V. V., \& Myhal'ska, L. M. (2013). Gerbicydy. Fiziko-himichni ta biolohichni vlastyvosti [Herbicides. Physical, chemical, and biological properties]. Logos, Kyiv (in Ukrainian).

Schwartau, V. V., Mykhalska, L. M., \& Miroshnichenko, I. M. (2016). Physiological role of amino acids in the nutrition of highly productive varieties of winter wheat. Sortovyvchennya ta Ohorona Prav na Sorty Roslyn, 3, 52-57.

Schwartau, V. V., Virych, P. A., Makoveychuk, T. I., \& Artemenko, A. U. (2014). Kal'ciy v rastitel'nyh kletkah [Calcium in Plant Cells]. Visnyk of Dnipropetrovsk University. Biology, Ecology, 22(1), 19-32 (in Russian).

Shekoofa, A., \& Emam, Y. (2008). Effects of nitrogen fertilization and plant growth regulators (PGRs) on yield of wheat (Triticum aestivum L.) cv. Shiraz Journal of Agricultural Science and Technology, 10(1), 101-108.

Stachecki, S., Praczyk, T., \& Adamczewski, K. (2004). Adjuvant effects on plant growth regulators in winter wheat. Journal of Plant Protection Research, 44(4), 365-371.

Virych, P. A., Vedmedenko, H. Y., \& Schwartau, V. V. (2014). Vliyanie trineksapak-ethila na soderzhanije pigmentov i anionov v list'jah pschenicy (Triticum aestivum L.) [Influence of trinexapac-ethyl on pigment and anionic content of wheat flag-leaf (Triticum aestivum L.)]. Naukovi Praci Instytutu Energetychnyh Kultur i Cukrovyh Buryakiv, 20, 17-20 (in Russian).

Zadoks, J. C., Chang, T. T., \& Konzak, C. F. (1974). A decimal code for the growth stages of cereals. Weed Research, 14, 415-421. 